\title{
Seasonal occurrence and distribition of brachyuran crabs caught along the Suez Canal, Egypt.
}

\author{
Marwa M. Osman', Wafaa S. Sallam², Fedekar F. Madkour ${ }^{3}$ and \\ Saad Z. Mohammed ${ }^{4}$ \\ 1,3 Department of Marine Sci., Fac. of Sci., Port Said Univ., Port Said, Egypt. \\ ${ }^{2,4}$ Department of Marine Sci., Fac. of Sci., Suez Canal Univ., Ismailia, Egypt. \\ Corresponding author: Marwa_Osman8@yahoo.com
}

\section{ABSTRACT}

The present study aimed to document the brachyuran crab fauna caught by fishing nets operating in the Suez Canal and study their occurrence and seasonal distribution along the canal during the period from April 2011 to March 2012. Five sampling locations were selected representing the known landing sites along the canal. Eleven species of crabs belonging to nine families were recorded, of them Dorippe quadridens and Cryptodromia hilgendorfi are recorded for the first time in the Suez Canal. The blue swimming crab Portunus pelagicus was the most distributed species in the study sites, followed by the spider crab Hyastenus hilgendorfi, while Coleusia signata and Cryptodromia hilgendorfi were the least common species. The present study discussed the seasonal occurrence and distribution of the recorded species and compared them with the previous studies conducted on the Suez Canal. The study recommended continuous monitoring of the brachyuran crabs fauna together with other crustaceans inhabiting the canal in order to provide an updated inventory and establish a database for the fauna of this unstable environment.

Keywords: Brachyuran crabs, distribution, occurrence, Suez Canal.

\section{INTRODUCTION}

The Suez Canal was completed in 1869, and since that date it linked two biogeographical provinces; the Mediterranean and the Red Seas (Boudouresque, 1999). It became an open gate for the Red Sea water to run along $163 \mathrm{~km}$ into the Mediterranean and vice versa. Stretching from Port Said in the north, the Suez Canal continues southward crossing Lake Timsah and the Bitter Lakes on its way to the city of Suez and the Gulf of Suez. The opening of the Suez Canal was the main reason of the most important biogeographic phenomenon witnessed in the contemporary oceans (Por, 1989). Some members of the Red Sea fauna have passed right through the Canal to spread into the Mediterranean, and some Mediterranean species have reached the Red Sea (Fox, 1924).

The ongoing influx of Red Sea biota into the Mediterranean Sea since the opening of the Suez Canal has drawn the attention of the scientific community (BenTuvia 1966; Por 1978; Galil 2009; Golani 2010). In the wake of the opening of the Suez Canal, each sea was exposed to an invasion of organisms from the other sea and to the establishment of some migrant species within the Canal itself (Golani, 1998). This influx of biota from the Red Sea into the Mediterranean through the Suez Canal has been termed "Lessepsian migration" (Por, 1978). This phenomenon incorporates almost all marine taxonomic groups. Nearly 300 Red Sea species are known to have entered the Mediterranean through the Suez Canal (Boudouresque, 1999). The minor migration in the opposite direction was termed by Por (1978) and known as "Anti- 
Lessepsian migration." However, the vast majority of migrational movement has been from the Red Sea to the Mediterranean.

The phenomenon of Lessepsian migration provides a unique opportunity to investigate, on a large scale, processes of migration, invasion and colonization, processes which usually occur over a geological time scale. No zoogeographic marine area of the world has been affected more by man-made changes than the eastern Mediterranean. The migrant species have serious impacts on the Mediterranean ecology, endangering many local and endemic Mediterranean species (Golani, 1998).

Due to the continuous changes in the ecological conditions of the Suez Canal, it was necessary to record the further spread of brachyuran crabs along the canal and to describe how successful the migration and establishment of these species has been in this environment. The purpose of this work is to provide an updated inventory for the brachyuran crabs caught by the fishing gear operating in the Suez Canal. It also aims to document their seasonal occurrence and patterns of distribution along the canal at the present time. This updated inventory will display the current status of brachyuran crabs in the canal which should facilitate further studies on this fauna by interested researchers.

\section{MATERIALS AND METHODS}

Five locations along the coast of the Suez Canal were selected for a survey conducted during the period between April 2011 to March 2012. These locations were selected since they are the best known landing sites along the length of the canal: Ismailia, on Timsah Lake. To the south: Fanara (on the Great Bitter Lake) and Shallufa (19 km north of Suez). To the north: El Kantara (on the Suez Canal proper) and Ras Elesh (17 km south of Port Said) (Fig. 1). Regular seasonal trips were carried out to the survey sites.

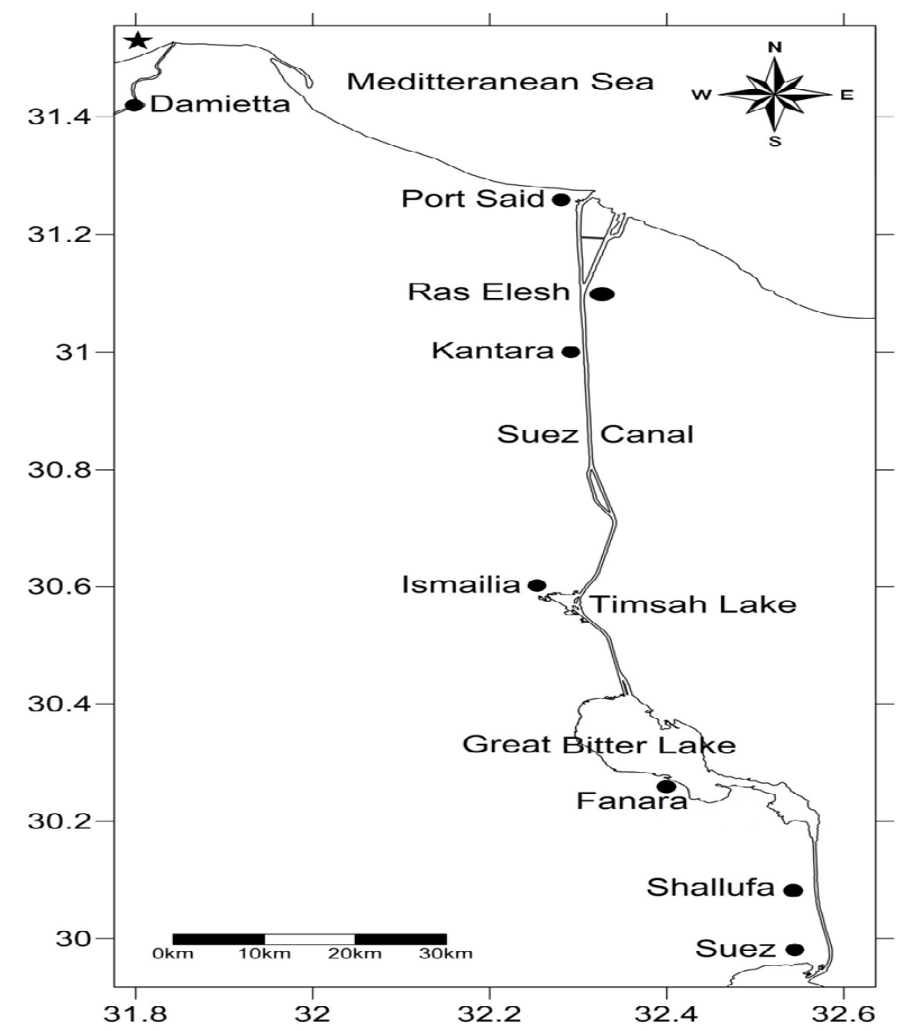

Fig. 1: The landing sites along the Suez Canal 


\section{Sample collection and preservation:}

Apart from Ras Elesh, all survey sites were visited in the early morning after the fishing boats had returned from their night time operation. Ras Elesh was visited late in the afternoon due to the daytime operation of the fishing vessels there. Catches were examined and sorted at each site and the occurrence of the different species was recorded. Samples were placed in labeled plastic jars and preserved in $10 \%$ formalin in seawater. For long term preservation, samples were transferred into $70 \%$ alcohol.

\section{Identification of specimens:}

The following texts were the main sources of species identification, synonymies and geographical distribution, Griffin and Tranter (1986), Wee and $\mathrm{Ng}$ (1995) and $\mathrm{Ng}$ et al. (2008).

\section{RESULTS}

A total of eleven species of brachyuran crabs were identified during the present survey (Plate 1). Table (1) shows a list of recorded species with information of their origin. The collected material included eleven genera belonging to nine families. The families Portunidae and Leucosiidae were represented by two species, while the other seven families Pisidae, Galenidae, Xanthidae, Euryplacidae, Dorippidae, Majidae and Dromiidae, each comprised only one species.

Table 1: List of the brachyuran crab species recorded in the present survey.

\begin{tabular}{|c|c|c|c|c|c|}
\hline No & Family & Genus & Species & Authority & Origin \\
\hline 1 & Pisidae & Hyastenus & hilgendorfi & De Man, 1887 & IP \\
\hline 2 & Galenidae & Halimede & tyche & (Herbst, 1801) & IP \\
\hline 3 & Xanthidae & Atergatis & roseus & (Rüppell, 1830) & IP \\
\hline 4 & Euryplacidae & Eucrate & crenata & De Haan, 1835 & IP \\
\hline 5 & Dorippidae & Dorippe & quadridens & (Fabricius, 1793) & IP \\
\hline 6 & Majidae & Schizophrys & dahlak & Griffin \& Tranter, 1986 & IP \\
\hline 7 & \multirow{2}{*}{ Leucosiidae } & Myra & subgranulata & Kossmann, 1877 & IP \\
\hline 8 & & Coleusia & signata & (Paulson, 1875) & IP \\
\hline 9 & \multirow{2}{*}{ Portunidae } & Charybdis & hellerii & (A. Milne Edwards, 1867) & IP \\
\hline 10 & & Portunus & pelagicus & (Linnaeus, 1758) & IP \\
\hline 11 & Dromiidae & Cryptodromia & hilgendorfi & De Man, 1888 & IP \\
\hline
\end{tabular}

\section{Legend:}

IP =Indo-Pacific (Source: CIESM Atlas of Exotic Species in the Mediterranean)

www.ciesm.org/atlas/appendix $2 . h t m l$

The presence and absence of the species recorded at each site during the survey period is shown in Table (2). The blue swimming crab, Portunus pelagicus (Linnaeus, 1758) was the most distributed species caught by fishermen nets in all sites along the coast of the Suez Canal. This species was recorded at all seasons except winter in Shallufa, El Kantara and Ras Elesh. The two spider crabs Hyastenus hilgendorfi De Man, 1887 and Halimede tyche (Herbst, 1801) were the second common species. Hyastenus hilgendorfi was absent only in spring in Shallufa and Ras Elesh and summer in El Kantara, while Halimede tyche was absent only in Shallufa during summer, Ismailia in winter and El Kantara in autumn. Coleusia signata (Paulson, 1875) and Cryptodromia hilgendorfi De Man, 1888 were the least common species caught and recorded only in spring in Ismailia.

Table (3) shows a list of brachyuran crabs reported with details of records by earlier workers. It is clear from the table that the Dorippid Dorippe quadridens (Fabricius, 1793) and the Dromiid Cryptodromia hilgendorfi De Man, 1888, are recorded for the first time in the Suez Canal in the present study. 
Table 2: Presence and absence of the species recorded at each site during the survey period

\begin{tabular}{|c|c|c|c|c|c|c|c|c|c|c|c|c|c|c|c|c|c|c|c|c|}
\hline \multirow[b]{2}{*}{ Species } & \multicolumn{4}{|c|}{ Shallufa } & \multicolumn{4}{|c|}{ Fanara } & \multicolumn{4}{|c|}{ Ismailia } & \multicolumn{4}{|c|}{ El Kantara } & \multicolumn{4}{|c|}{ Ras Elesh } \\
\hline & 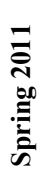 & 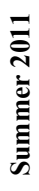 & 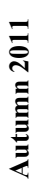 & 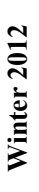 & 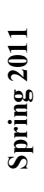 & 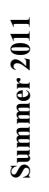 & 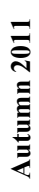 & 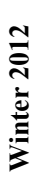 & 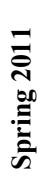 & 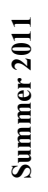 & 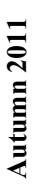 & 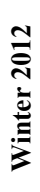 & 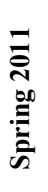 & 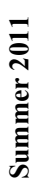 & 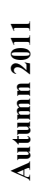 & 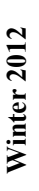 & 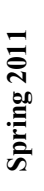 & 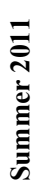 & 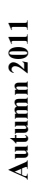 & 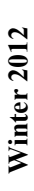 \\
\hline $\begin{array}{l}\text { Portunus } \\
\text { pelagicus }\end{array}$ & + & + & + & - & + & + & + & + & + & + & + & + & + & + & + & - & + & + & + & - \\
\hline $\begin{array}{l}\text { Hyastenus } \\
\text { hilgendorfi }\end{array}$ & - & + & + & + & + & + & + & + & + & + & + & + & + & - & + & + & - & + & + & + \\
\hline $\begin{array}{c}\text { Halimede } \\
\text { tyche }\end{array}$ & + & - & + & + & + & + & + & + & + & + & + & - & + & + & - & + & + & + & + & + \\
\hline $\begin{array}{c}\text { Schizophrys } \\
\text { dahlak }\end{array}$ & - & + & + & + & + & + & - & - & + & + & + & - & + & - & + & - & + & + & + & + \\
\hline $\begin{array}{c}\text { Charybdis } \\
\text { hellerii }\end{array}$ & - & + & - & + & - & - & + & + & + & + & + & + & + & - & + & - & + & + & - & - \\
\hline $\begin{array}{l}\text { Eucrate } \\
\text { crenata }\end{array}$ & - & - & + & + & - & - & - & + & + & + & - & + & + & + & - & - & + & + & - & - \\
\hline $\begin{array}{c}\text { Atergatis } \\
\text { roseus }\end{array}$ & - & - & - & - & - & - & - & + & - & - & + & - & + & - & + & - & - & - & + & - \\
\hline $\begin{array}{c}\text { Myra } \\
\text { subgranulata }\end{array}$ & - & - & + & - & - & - & - & + & + & - & - & + & - & - & - & - & - & - & - & - \\
\hline $\begin{array}{c}\text { Dorippe } \\
\text { quadridens }\end{array}$ & - & - & - & + & - & - & - & - & - & - & + & - & - & - & - & - & - & - & + & - \\
\hline $\begin{array}{c}\text { Coleusia } \\
\text { signata }\end{array}$ & - & - & - & - & - & - & - & - & + & - & - & - & - & - & - & - & - & - & - & - \\
\hline $\begin{array}{c}\text { Cryptodromia } \\
\text { hilgendorfi }\end{array}$ & - & - & - & - & - & - & - & - & + & - & - & - & - & - & - & - & - & - & - & - \\
\hline
\end{tabular}

Legend : (+), present; (-), absent.

Table 3: List of brachyuran crabs with details of records by earlier workers

\begin{tabular}{|c|c|c|c|c|c|c|c|c|c|}
\hline No & Species & 胥 气ૂ & 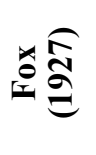 & 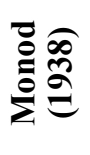 & 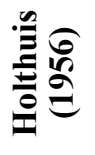 & 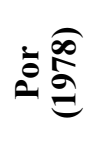 & 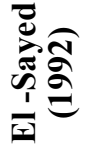 & 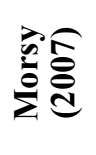 & 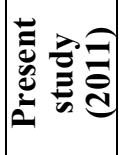 \\
\hline 1 & $\begin{array}{l}\text { Family: Pisidae } \\
\text { Hyastenus hilgendorfi }\end{array}$ & + & + & + & + & + & + & + & + \\
\hline 2 & $\begin{array}{l}\text { Family: Euryplacidae } \\
\text { Eucrate crenata }\end{array}$ & + & + & + & + & + & + & + & + \\
\hline 3 & $\begin{array}{l}\text { Family: Leucosiidae } \\
\text { Coleusia signata }\end{array}$ & + & + & + & + & + & + & + & + \\
\hline 4 & $\begin{array}{l}\text { Family: Portunidae } \\
\text { Portunus pelagicus }\end{array}$ & - & + & + & + & + & + & + & + \\
\hline 5 & $\begin{array}{l}\text { Family: Galenidae } \\
\text { Halimede tyche }\end{array}$ & - & - & - & - & - & + & + & + \\
\hline 6 & $\begin{array}{l}\text { Family: Xanthidae } \\
\text { Atergatis roseus }\end{array}$ & - & - & - & - & - & + & + & + \\
\hline 7 & $\begin{array}{l}\text { Family: Majidae } \\
\text { Schizophrys dahlak }\end{array}$ & - & - & - & - & - & + & + & + \\
\hline 8 & $\begin{array}{l}\text { Family: Portunidae } \\
\text { Charybdis hellerii }\end{array}$ & - & - & - & - & - & + & - & + \\
\hline 9 & $\begin{array}{l}\text { Family: Leucosiidae } \\
\text { Myra subgranulata }\end{array}$ & - & - & - & - & - & - & + & + \\
\hline 10 & $\begin{array}{l}\text { Family: Dorippidae } \\
\text { Dorippe quadridens }\end{array}$ & - & - & - & - & - & - & - & + \\
\hline 11 & $\begin{array}{l}\text { Family: Dromiidae } \\
\text { Cryptodromia hilgendorfi }\end{array}$ & - & - & - & - & - & - & - & + \\
\hline
\end{tabular}




\section{DISCUSSION}

The material collected during the present study shows that the number of brachyuran crab species caught by the fishing gear in the Suez Canal is quite low, considering the fact that this water body joints between two seas; the Mediterranean and the Red Seas. The most recent study (Morsy, 2007) reported 10, species while ElSayed (1992) reported 25 species. However, our sampling technique differs than that of El-Sayed who collected specimens not only from the fishing nets but also from all types of substrates in the canal. Furthermore, his survey was only limited to the three lakes (Timsah and Bitter Lakes) while ours was carried out along the Suez Canal.

Portunus pelagicus, Hyastenus hilgendorfi, Halimede tyche and Schizophrys dahlak were the most distributed species, being found with large populations at most of the sites and most of the seasons (Table 2). This result points out the fact that these species are well established in the different habitats along the Suez Canal. It also indicates that the environmental conditions of the different sites do assist with their presence particularly in terms of nature of bottom, food availability and absence of predators. Drickamar and Vessy (1982) stated that if a species occupies an area and reproduces there, this means that all its needs are met.

The present study added two species; Dorippe quadridens and Cryptodromia hilgendorfi as first records to the number of brachyuran crab fauna reported in previous studies conducted in the canal waters (Calman, 1927; Fox, 1927; Monod, 1938; Holthuis, 1956; Por, 1978; El-Sayed, 1992 and Morsy, 2007). This ongoing change in the structure of the crab community of the Suez Canal is definitely due to the continuous migration activity of marine organisms from the Red Sea to the Mediterranean via the canal. Rodríguez and Suárez (2001) mentioned that, there are 40 species of decapods in the Mediterranean accounted for as Lessepsian migrants. The fact that the origin of all species recorded in the present study is Indo Pacific (Table 1) indicates that they all have migrated from the Red Sea. This in turn confirms the phenomenon of Lessepsian migration which is described by Por (1978) as unidirectional. Aron and Smith (1974) and Por (1978) claimed that the environmental conditions and community structure of the Mediterranean favor colonizers from the Red Sea, whereas colonizers from the Mediterranean are far less adapted to successfully colonize the Red Sea.

The results obtained in the present study reveal that the brachyuran crab fauna caught from the Suez Canal is in state of constant change, with species newly arriving or disappearing. The ongoing variations in the occurrence of species reflect the need to establish a continuous monitoring program for the canal. Regular visits should be paid to the landing sites in order to update the inventory of crustacean species existing in the canal. Furthermore, the sampling plan should expand to include all types of substrates. This program will be particularly essential especially with the new expansion project of the canal which is claimed to facilitate the migration of species between the two seas.

\section{REFERENCES}

Aron, W. I. and Smith, S. H. (1974). Ship canals and aquatic ecosystems. Sci., 174:13-20.

Ben-Tuvia, A. (1966). Red Sea fishes recently found in the Mediterranean. Copeia 1966: 254-275. 
Boudouresque, C. F. (1999). The Red Sea-Mediterranean link: unwanted effects of canals. In: Sandlund, O.T., Schei, P.J., Viken, A. (Eds.), Invasive Species and Biodiversity Management. Kluwer Academic Publishers, Dordrecht, NDL, pp. 213-228.

Calman, W. T. (1927). Report on the Crustacea Decapoda (Brachyura). Zoological result of the Cambridge expedition to the Suez Canal 1924 XIII. Trans. Zool. Soc. Fond., 22: 211-217

Drickamar, L. C. and Vessey, S. H. (1982). Animal Behavior: Concepts, processes and methods. Willard Grant Press. Boston, $510 \mathrm{pp}$.

El-sayed, A. A. M. (1992). Biological studies on some brachyuran crabs (Crustacea) from Suez Canal. Ph. D. Thesis (Al-Azhar University).

Fox, H. M. (1924). The migration of a Red Sea crab through the Suez Canal. Nature, (London), 113:714-715.

Fox, H. M. (1927). Appendix to the report on the Crustacea Decapoda (Brachyura). Zoological Results of the Cambrigde Expedition to the Suez Canal, 1924. Trans. Zool. Soc. London, 22: 843-863.

Griffin, D. J. G. \& H. A. Tranter, 1986. The Decapoda Brachyura of the Siboga Expedition. Part VIII. Majidae. Siboga-Exped., 39(C4): 1-335.

Galil, B. S. (2009). Taking stock: inventory of alien species in the Mediterranean Sea. Biol. Inv., 11: 359-372.

Golani, D. (1998). Impact of Red Sea fish migrants through the Suez Canal on the aquatic environment of the eastern Mediterranean. Bull. Yale School Forest. Environ. Stud., 103: 375-387.

Golani, D. (2010). Colonization of the Mediterranean by Red Sea Fishes via the Suez Canal-Lessepsian Migration. In: Golani D, Appelbaum-Golani B (eds) Fish Invasions of the Mediterranean-Change and Renewal. Sofia: Pensoft, pp. $145-188$

Holthuis, L. B. (1956). Notes on a collection of Crustacea Decapoda from the great Bitter Lake, Egypt, with a list of the species of Decapoda known from the Suez Canal. Zool. Meded. Leiden., 34(22): 301-330.

Monod, T. (1938). Decapoda Brachyura. In: mission Robert Ph. Dollfus en Egypte. VIII. Mem. Inst. Egypt, 37: 91-162.

Morsy, N. K. M. (2007). Studies on Fishery and Biology of the Brachyuran crabs of the Suez Canal. Ph. D. Thesis, Suez Canal University.

Ng. P. K. I.; Guinot, D. and Davie, P. F. (2008). Systema Brachyurorum: An annotated checklist of extant brachyuran crabs of the world. The Raffles Bulletin of Zoology, 17: 1-286.

Por, F. D. (1978). Lessepsian migration. The influx of Red Sea biota into the Mediterranean by way of the Suez Canal. Springer-Verlag. Berlin Heidelberg, New york, $277 \mathrm{pp}$.

Por, F. D. (1989). The legacy of Tethys: an aquatic biogeography of the Levant, Kluwer Academic Publishers Group, Dordrecht, The Netherlands.

Rodríguez, G. and Suárez, H. 2001. Anthropogenic dispersal of decapod crustaceans in aquatic environments. Interciencia, 26(7): 282-288.

Wee, D. P. C and Ng, P. K. L. (1995). Swimming crabs of the genera charybdis De Haan, 1833, and Thalamita Latereille, 1829 (Crustacea: Decapoda: Brachyura: Portunidae) from Peninsular Malaysia and Sinsapore. The Raffles Bulletin of Zoology, pp 1-128. 


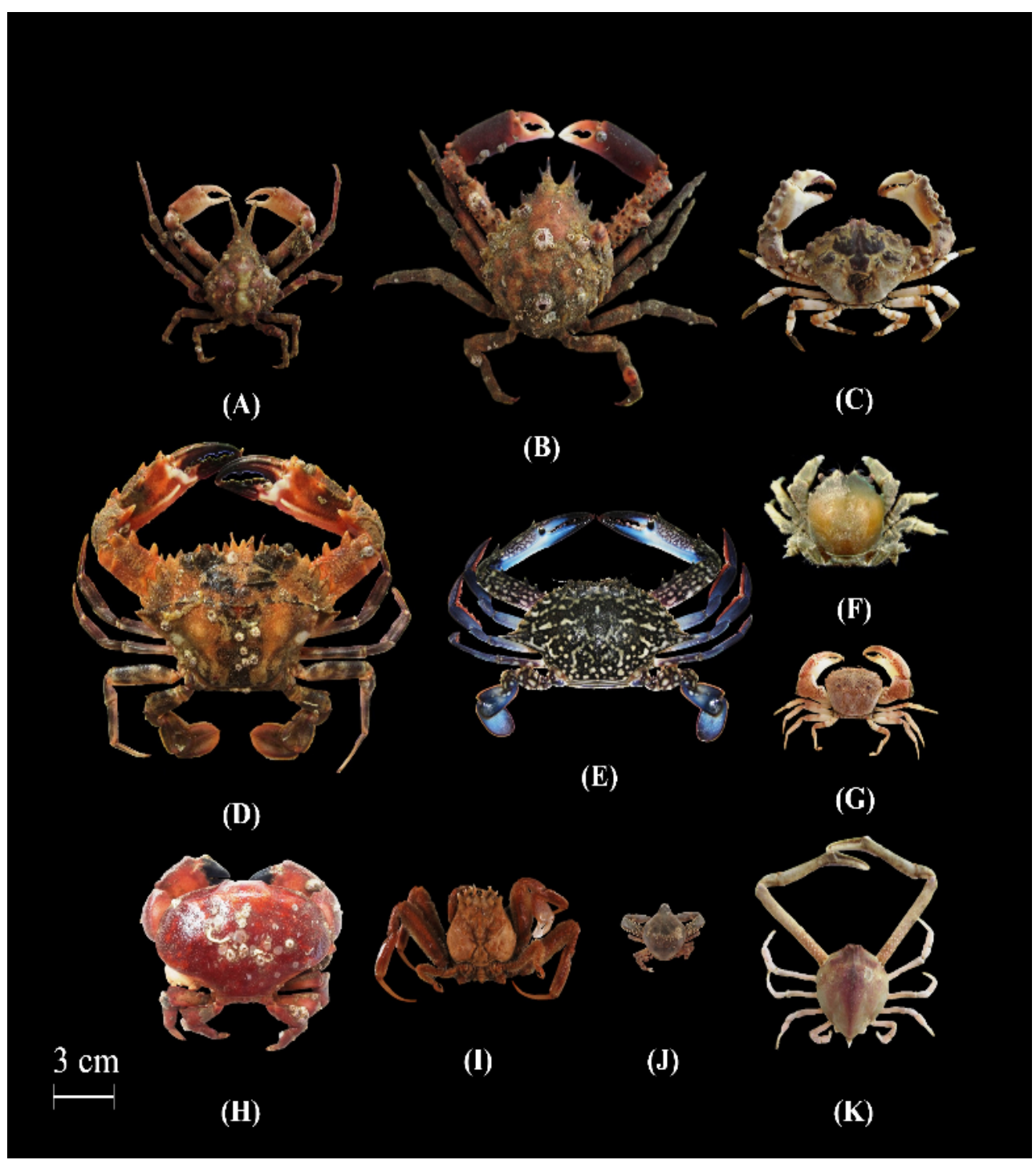

Plate 1. Identified crab species of the present study: (A) Hyastenus hilgendorfi (B) Schizophrys dahlak (C) Halimede tyche (D) Charybdis hellerii (E) Portunus pelagicus (F) Cryptodromia hilgendorfi (G) Eucrata crenata (H) Atergatis roseus (I) Dorippe quadridens (J) Coleusia signata (K) Myra subgranulata. 


\section{ARABIC SUMMARY}

\section{التواجد الموسمى و توزيع السرطانات مختزلة البطن المصاده بإمتداد قناة السويس، مصر.

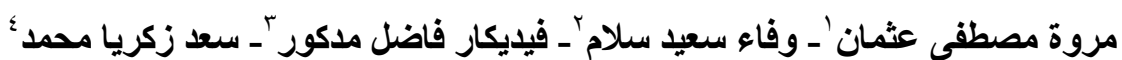

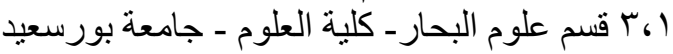

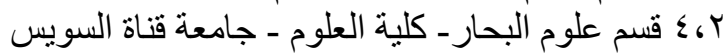

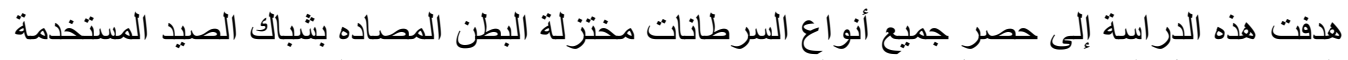

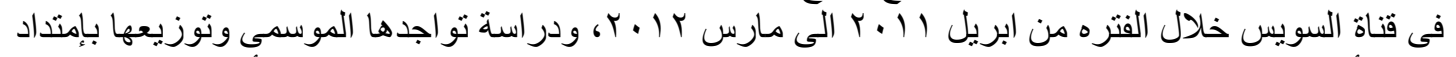

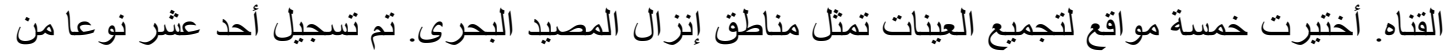

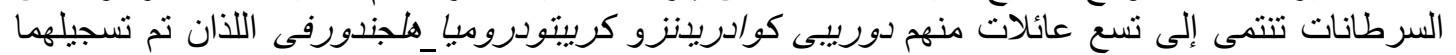

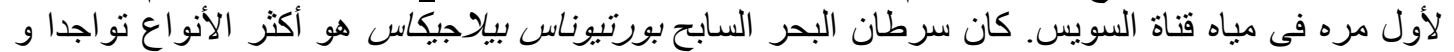

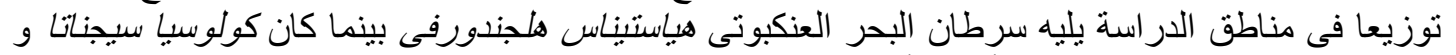

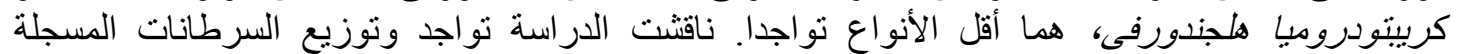

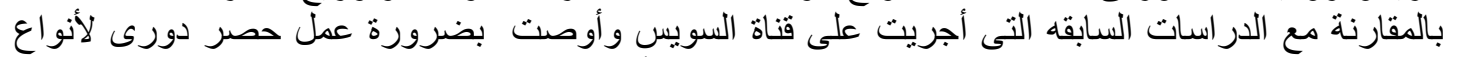
السرطانات وغير ها من القشريات القاطنة بالقناه وذللك من أجل إنشاء قاعدة بيانات التهات لفونة هذه البيئه الدائمة التغبر. 